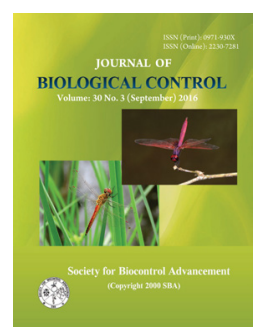

\title{
Biological attributes and feeding potential of three dominant predators of Lipaphis erysimi (Kaltenbach)
}

\author{
N. S. MANPOONG ${ }^{*}$ D. M. FIRAKE ${ }^{1}$, G. T. BEHERE ${ }^{1}$ and T. RAJESH \\ School of Crop Protection, College of Post-Graduate Studies (Central Agricultural University), Umiam - 793103, Meghalaya, India \\ ${ }^{1}$ Division of Crop Protection, ICAR Research Complex for NEH region, Umiam - 793103, Meghalaya, India \\ ${ }^{*}$ Corresponding author E-mail: mystiksena@gmail.com
}

\begin{abstract}
Basic biological attributes and feeding potential of three major predators viz., the seven spotted lady bird beetle Coccinella septempunctata Linnaeus and two syrphids Episyrphus viridaureus (Wiedemann) and Betasyrphus isaaci (Bhatia), of mustard aphid, Lipaphis erysimi were studied under laboratory conditions. The predators were multiplied on mustard aphids reared on mustard plants. C. septempunctata, E. viridaureus and B. isaaci completed their life cycle in $68.5 \pm 6.5$ days, $47 \pm 2$ and $41 \pm 2$, respectively. Coccinella septumpunctata completed the larval growth with four larval instars, while both the syrphids terminated the larval growth with three instars. Final instars of all the three predators were found to have highest predatory potential than the younger instars. C. septumpunctata was found to be the most dominant predator of mustard aphid with average lifetime consumption of $4312 \pm 537.74$ aphids, followed by E. viridaureus (416.67 \pm 6.76 aphids) and B. isaaci (338 \pm 7.89 aphids). All the three predators have the potential to reduce the mustard aphids; however, $C$. septumpunctata has a maximum predatory potential with a longer life, which makes this species as an excellent bioagent of L. erysimi and further research on their utilization on a large scale should be undertaken.
\end{abstract}

KEY WORDS: Betasyrphus isaaci, Coccinella septempunctata, Episyrphus viridaureus, Lipaphis erysimi, Meghalaya

(Article chronicle: Received: 15-07-2016; Revised 02-09-2016; Accepted: 05-09-2016)

Indian mustard (Brassica juncea L.) is an agriculturally important oilseed crop and contributes as a major source of edible oil in the country. In terms of area and production, it ranks second among the oilseed crop next to the groundnut (Singh and Singh, 2013). India produces about $11.3 \%$ of the world's rapeseed and mustard (Pramanik and Dey, 2012). However, the average yield of mustard is relatively low in India compared to the other countries (Rao et al., 2013). Insect-pests are one of the important factors for low productivity of mustard that cause significant reduction in yield. Amongst the insect pests, the mustard aphid, Lipaphis erysimi Kaltenbach (Hemiptera: Aphididae) is one of the most destructive insects and a major limiting factor for successful cultivation of mustard. Mustard aphid is a widely distributed pest, causes damage from seedlings till the harvesting stage and which alone can cause up to $73.3 \%$ reduction in yield (Gupta et al., 2003). The yield losses varied from 30-40 \%, depending upon the season and localities (Sultana et al., 2009). Although synthetic chemical pesticides are widely used to manage the mustard aphid, they harm the ecosystem in several ways. As more emphasis is being given on natural and organic farming, it is important to find out the eco-friendly approaches for pest management, for maintaining ecosystem health and human nutrition through balanced food chain in agro-ecosystems.

Due to a distinct climatic conditions, the northeastern hilly region of India is exceptionally rich in terms of flora and fauna (Azad Thakur et al., 2012; Firake et al., 2013a). The brassicaceous ecosystems of Meghalaya harbour several natural enemies, many of them have a potential to reduce the pest damage (Firake et al., 2012a; Lytan and Firake, 2012; Firake et al., 2012b; Thubru et al., 2016). Among predators, the ladybird beetle, Coccinella septumpunctata Linnaeus (Coleoptera: coccinellidae) and syrphid flies, Episyrphus viridaureus (Wiedemann) and Betasyrphus isaaci (Bhatia) (Diptera: Syrphidae) are the major predators of mustard aphid in mid altitude hills of Meghalaya. These potential natural enemies can be utilized to develop an effective bio-intensive pest management modules against target pests. Basic biological attributes and functional response of major natural enemies are very much essential to utilize them judiciously. However, this information is limited, particularly in case of syrphid flies. Consequently, the biological attributes and feeding potential of C. septempunctata and syrphid flies (E. viridaureus and $B$. 
isaaci) were studied under in vitro conditions, to know their efficiency, potential and further benefits in the management of mustard aphid.

The experiments were conducted in Entomology Section, Division of Crop Protection, ICAR Research Complex for NEH region, Umiam, Meghalaya. The mustard variety 'M-27' was grown on the entomology farm of the institute. All three natural enemies viz., E. viridaureus, B. isaaci and C. septempunctata and mustard aphid, L. erysimi were collected from the field and further used for the experiments.

The stock cultures of natural enemies were maintained (at $20 \pm 1^{\circ} \mathrm{C}$ Temperature, $75 \%$ Relative humidity, 10:14, L: D Light hours) on the aphid infested mustard plants in the laboratory. For that, mustard seeds (variety 'M-27') was planted in small plastic jar and raised inside the net house. Initial culture of aphid, L. erysimi was collected from the entomology farm of the institute. At 35 days of planting, mature aphids were gently released on mustard plants @10 aphid per plant with the help of camel hair brush. The infested plants were brought into the laboratory after 15-25 days of release. The larvae of natural enemies viz. E. viridaureus, B. isaaci and C. septempunctata were collected from the entomology farm and released inside the wooden rearing cages $(45 \times 45 \times 45 \mathrm{~cm})$ containing infested mustard plants. The host plants were produced regularly during experimental period and the natural enemies were multiplied on aphid, L. erysimi developing on mustard plants.

For the experiment, mated females of ladybird beetle $(n=30)$ and syrphid flies $(n=20)$ were released in a plastic jar containing mustard aphid. Eggs laid on the leaves or periphery of the plastic jar were collected gently with a soft camel hair brush and kept in petri-plates. The newly hatched larvae of different predators were allowed to feed upon the aphids inside the plastic jar till attaining their adult stage. Fresh food was provided regularly until completion of their growth and development. Observations on incubation period, larval (instar wise) and pupal period were recorded regularly. Adults of all three predators $(n=10$ pairs $)$ were separated immediately after the emergence and kept in specially developed oviposition chamber for eggs laying. Fresh twigs of mustard plants containing sufficient numbers of aphids and honey solution (50\%) were provided to adults till their death. Observations on adult longevity and fecundity were recorded regularly.

To study the predatory potential of coccinellids and syrphid flies, ten newly hatched larvae of different predators were released in a separate Petri dishes. The mustard aphids were provided regularly @, 100 live mature aphids per larva. After 24 hours, observation on consumption of aphids was recorded from each plate regularly and provided with fresh aphids in Petri dishes. The process was repeated until the complete growth of the predators. Observations on different life stages were also recorded regularly to know the most efficient stage of the predators. Adult syrphid flies are free living and therefore the observations on syrphid predators were only recorded up to final larval instars. In case of $C$. septumpunctata, the feeding potential was also recorded in the adult stage. In addition to aphids (@,100 aphids/day), honey solution (50\%) was also provided regularly to the adult beetles until their death. Average values and standard error of the mean were calculated with Microsoft office Excel 2007 Windows 7.0.

\section{Biological attributes of the predators under laboratory conditions}

\section{Coccinella septempunctata}

The adult female, laid yellow coloured eggs in cluster of around 26-45 in numbers. The incubation period was found to be $3.5 \pm 0.5$ days. The grub of $C$. septempunctata underwent four larval instars. The size of the grub increased with each consecutive moulting. The total larval period was observed to be $26 \pm 3$ days. The pupa of $C$. septempunctata was grey to black in colour with orange marking on the outside. The size of the pupa was approximately as same size of the adult. The pupal period was found to be $7.5 \pm 1.5$ days. The adult female lived for $31.5 \pm 1.5$ days and laid $357.45 \pm 22.41$ eggs in her lifetime. The earlier reports on biology of C. septempunctata (Xu 1985; Rauf et al., 2013; Sattar et al., 2008) are in conformity with our results and slight variation in developmental period could be due to different factors including prey species and host plants.

\section{Episyrphus viridaureus}

Singly laid eggs of E. viridaureus were observed near or within aphid colonies. The eggs were whitish in colour and oblong in shape. The incubation period was found to be $3 \pm 0.5$ days. E. viridaureus underwent three larval instars to complete larval growth. Interestingly, the maggot of $E$. viridaureus had a transparent body, enables the clear visibility of the internal organs. The larval period was observed to be $22 \pm 1.5$ days. The pupa of $E$. viridaureus was creamy coloured and pear shaped, tapering at the end. The pupal period was found to be $7 \pm 1$ day. Adult female lived for $14 \pm 1.5$ days and laid $45.0 \pm 16.8$ eggs in her lifetime. The fly completes its life cycle in 47 to 49 days. While studying biology of E. balteatus, Hong and Hung (2010) found 21.2 days life cycle of $E$. balteatus with larval period of 7.6 days. 


\section{Betasyrphus isaaci}

The adult female of $B$. isaaci laid egg singly near aphid colonies. The eggs were faint grey in colour and oblong shaped. The incubation period was found to be $3 \pm 1$ day. The total larval period was observed to be $21 \pm 1.5$ days and larva underwent three larval instars. The pupal period was found to be $8 \pm 1$ day. The adult female lived for $13 \pm 1$ days and laid $31.2 \pm 13.6$ in her lifetime.

\section{Feeding potential of three predators of mustard aphid}

Data on predatory potential of three major natural enemies are presented in Table 2. In case of all three predators, consumption of aphids was found to increase with each subsequent instars and final larval instar consumed maximum aphids than the younger ones. Predatory potential of immature stages of $C$. septumpunctata was found to be much higher than both the species of syrphid flies. A single adult $C$. septumpunctata consumed an average of $81.55 \pm 15.34$ aphids per day and ultimately consumed $2691.00 \pm 533$ aphids during adult stage. Since both immature and adult stage of $C$. septumpunctata are predatory and therefore it was found to be the most dominant predator of $L$. erysimi. A single C. septumpunctata consumed an average of $4312 \pm 537.74$ aphids in a lifetime; which is much higher than $E$. viridaureus (416.67 \pm 6.76 aphids) and B. isaaci ( $338 \pm 7.89$ aphids). Higher consumption dur- ing last larval instar could be attributed to the complete development of mouth parts and higher metabolism than early instars. Our results are supported by several findings on feeding potential of different syrphids and coccinellids (Baskaran et al., 2009; Romabai Devi et al., 2011; Verma et al., 2005; Alfiler and Calilung, 1980; Bunker and Ameta, 2009; Singh and Singh, 2013, 2014). Singh and Singh (2013) reported that the first, second, third and fourth instar of C. septumpunctata consumed 21.43, 46.90, 72.61, and 102.60 aphids per day. The total consumption of $E$. viridaureus was reported to be $464 \pm 21.65$ aphids (Kotwal et al., 1984). The prey consumption of Episyrphus spp. is known to increase gradually with the age of the developing instars (Romabai Deviet al., 2011), as observed in this study. The information on feeding potential of $B$. issaci is not available in the existing literature, however, Verma et al. (2005) reported that the first, second and third instar of another closely related syrphid, B. serarius consumed 11.5, 44.75 and 232.5 aphids/day.

The present study concludes that all the three predators have the potential to reduce the mustard aphids. The $C$. septumpunctata has a maximum predatory potential with a longer life, which makes this species as an excellent bioagent of $L$. erysimi and further research on their utilization on large scale should be addressed.

Table 1. Biological attributes of three predators of mustard aphids under laboratory conditions

\begin{tabular}{llll}
\hline Parameter & \multicolumn{3}{c}{ Predators } \\
\cline { 2 - 4 } & Coccinella septempunctata & Episyrphus viridaureus & Betasyrphus isaaci \\
\hline Incubation period & $3.5 \pm 0.5$ days & $03 \pm 0.5$ days & $3 \pm 1$ days \\
Larval period & $26 \pm 3$ days & $22 \pm 1.5$ days & $21 \pm 1.5$ days \\
First instar & $3.5 \pm 0.5$ days & $12.9 \pm 1.0$ days & $13.10 \pm 0.5$ days \\
Second instar & $7.5 \pm 1.5$ days & $4.1 \pm 0.5$ days & $3.90 \pm 1.0$ days \\
Third instar & $6.5 \pm 0.5$ days & $5.0 \pm 1.0$ days & $4.0 \pm 0.5$ days \\
Fourth instar & $8.5 \pm 1.0$ days & - & - \\
Pupal period & $7.5 \pm 1.5$ Days & $7 \pm 1$ days & $8 \pm 1$ days \\
Adult longevity & $31.5 \pm 1.5$ Days & $14 \pm 1.5$ days & $13 \pm 1$ days \\
Life cycle & $68.5 \pm 6.5$ Days & $47 \pm 2$ days & $41 \pm 2$ days \\
Fecundity & $357.45 \pm 22.41$. No/female & $45.0 \pm 16.8$. No/female & $31.2 \pm 13.6$. No/female \\
\hline
\end{tabular}

Table 2. Feeding potential of three major predators on Lipaphis erysimi

\begin{tabular}{|c|c|c|c|c|c|c|}
\hline \multirow[t]{2}{*}{ Stages } & \multicolumn{3}{|c|}{ Daily consumption of aphids per day (Mean $\pm \mathrm{SE})$} & \multicolumn{3}{|c|}{ Consumption per life stage (Mean \pm SE) } \\
\hline & $\begin{array}{l}\text { Coccinella sep- } \\
\text { tempunctata }\end{array}$ & $\begin{array}{l}\text { Episyrphus viri- } \\
\text { daureus }\end{array}$ & $\begin{array}{l}\text { Betasyrphus } \\
\text { isaaci }\end{array}$ & $\begin{array}{l}\text { Coccinella sep- } \\
\text { tempunctata }\end{array}$ & $\begin{array}{l}\text { Episyrphus viri- } \\
\text { daureus }\end{array}$ & $\begin{array}{l}\text { Betasyrphus } \\
\text { isaaci }\end{array}$ \\
\hline First instar & $20.42 \pm 00.42$ & $07.30 \pm 0.08$ & $06.51 \pm 0.17$ & $081.67 \pm 0.33$ & $095.00 \pm 1.51$ & $084.67 \pm 1.30$ \\
\hline Second instar & $35.00 \pm 00.99$ & $23.58 \pm 0.22$ & $23.75 \pm 0.29$ & $315.00 \pm 1.34$ & $094.00 \pm 4.30$ & $095.00 \pm 4.80$ \\
\hline Third instar & $65.48 \pm 01.27$ & $45.53 \pm 1.09$ & $39.58 \pm 1.46$ & $458.33 \pm 1.29$ & $227.67 \pm 0.95$ & $158.33 \pm 1.79$ \\
\hline Fourth instar & $85.11 \pm 01.39$ & - & - & $766.00 \pm 1.78$ & - & - \\
\hline Adult & $81.55 \pm 15.34$ & Free living & Free living & $2691.00 \pm 533$ & Free living & Free living \\
\hline $\begin{array}{l}\text { Total consump- } \\
\text { tion }\end{array}$ & & & & $4312 \pm 537.74$ & $416.67 \pm 6.76$ & $338.00 \pm 7.89$ \\
\hline
\end{tabular}




\section{ACKNOWLEDGEMENTS}

This manuscript is the part of the M.Sc. thesis of the first author, submitted to the College of Post-Graduate Studies, CAU, Barapani, Meghalaya and the merit scholarship received during the course of studies is duly acknowledged. The authors are thankful to the Director, ICAR Research Complex for NEH Region and Dean, CPGS, Umiam, Meghalaya for providing necessary facilities during the course of study. The authors are also grateful to the student advisory committee member, Dr. N. S. Azad Thakur for his critical advice during the study.

\section{REFERENCES}

Alfiler ARR, Calilung VJ. 1980. The life-history and voracity of the syrphid predator, Ischiodon scutellaris (F.) (Diptera: Syrphidae). Philippine Entomol. 4(1/2): 105-117.

Thakur NSA, Firake DM, Behere GT, Firake PD, Saikia K. 2012. Biodiversity of agriculturally important insects in North Eastern Himalaya: An overview. Indian J Hill Fmg 25: 37-40.

Baskaran RKM, Sasikumar S, Rajavel DS, Suresh K. 2009. Biology and predatory potential of aphidophagous syrphids on guava aphid, Aphis gossypii (Glover) (Hemiptera : Aphididae). J Biol Control 23(1): 53-56.

Bunker GK, Ameta OP. 2009. Predation potential of Coccinella septempunctata L., Cheilomenes sexmaculata F. and Chrysoperla carnea (Stephens) on different aphid species. Indian J Ent. 71(1): 76-79.

Firake DM, Behere GT, Firake PD, Rajkhoa DJ, Azad Thakur NS, Saini MS, Rahman Z, Ngachan SV. 2013a. Arge xanthogaster (Hymenoptera: Argidae): A new threat to rose plants in Meghalaya, India. Florida Entomol. 96(4): 1298-1304.

Firake DM, Behere GT, Deshmukh NA, Firake PD, Thakur NSA. 2013b. Recent scenario of insect-pests of guava in northeast India and their eco-friendly management. Indian J Hill Fmg 26(1): 55-57.

Firake DM, Lytan D, Behere GT, Thakur NSA. 2012a. Host plants alter the reproductive behavior of cabbage butterfly, Pieris brassicae (Lepidoptera: Pieridae) and its endo-larval parasitoid, Hyposoter ebeninus (Hymenoptera: Ichenuomonidae) in cruciferous ecosystems. Florida Entomol. 95(4): 905-913.
Firake DM, Lytan D, Behere GT. 2012b. Bio-diversity and seasonal activity of arthropod fauna in brassicaceous crop ecosystems of Meghalaya, North East India. Mol Entomol. 3(4): 18-22.

Gupta MP, Verma ML, Churasia SK. 2003. Assessment of avoidable yield losses in Karan Rai varieties due to mustard aphids. Ann Pl Prot Sci. 11: 11-15.

Hong BM, Hung HQ. 2010. Effect of temperature and diet on the life cycle and predatory capacity of Episyrphus balteatus (De Geer) (Syrphidae: Diptera) cultured on Aphis gossypii (Glover). J ISSAAS 16(2): 98-103.

Kotwal DR, Bhalla DP, Verma AK. 1984. Natural enemies of cabbage aphid, Brevicoryne brassicae (Linn.) in the mid-hill regions of Himachal Pradesh. Indian J Agric Sci. 54: 1011-1012.

Lytan D, Firake DM. 2012. Effects of different host plants and rearing atmosphere on life cycle of large white cabbage butterfly, Pieris brassicae (Linnaeus). Arch Phytopath Pl Prot. 45: 1819-1825.

Pramanik A, Dey D. 2012. Influence of weather parameters on population dynamics of Lipaphis erysimi (Kaltenbach) (Hemiptera: Aphididae) and its parasitoid Diaeretiella rapae (McIntosh) (Hymenoptera: Braconidae) in mustard. $J$ Ent Res. 36(4): 305-308.

Rao BB, Rao VUM, Nair L, Prasad YG, Ramaraj AP, Chattopadhyay C. 2013. Assessing aphid infestation in Indian mustard (Brassica juncea L.) under present and future climate scenarios. Bangladesh J Agril Res. 38(3): 373-387.

Rauf M, Ehsan-ul-Haq Khan J, Rehman A, Gillani WA, Ali A. 2013. Biology and predatory potential of Coccinella septempunctata Linn. on Schizaphis graminum aphid under controlled conditions. Pakistan J Agric Res. 26(2): 124-129.

Romabai Devi Y, Kalita J, Singh TK. 2011. Biological control potential of an aphidophagous syrphid, Episyrphus balteatus, De-Geer (Diptera: Syrphidae) on mustard aphid, Lipaphis erysimi (Kalt.)(Homoptera: Aphididae) on cabbage ecosystem in Manipur. $J$ Exp Sci. 2(12): 13-16.

Sattar M, Hamed M, Nadeem S. 2008. Biology of Coccinella septempunctata Linn. (Coleoptera: Coccinellidae) and its predatory potential on cotton aphids, Aphis gossy- 
pii Glover (Hemiptera: Aphididae). Pakistan J Zool. 40(4): 239-242.

Singh K, Singh NN. 2013. Preying capacity of different established predators of the aphid Lipaphis erysimi (Kalt.) infesting rapeseed-mustard crop in laboratory conditions. Pl Prot Sci. 49(2): 84-88.

Singh K, Singh NN. 2014. Biology and devouring propensity of lady bird beetle, Coccinella septempunctata Linnaeus on rapeseed-mustard aphid, Lipaphis erysimi Kaltenbach. Afr J Agric Res. 9(1): 61-64.

Sultana NA, Khan MAH, Isla MN, Hasanuzzaman M. 2009. Integrated management of aphid (Lipaphis erysimi Kalt.) in mustard. World J Zool. 4(2): 105-108.
Thubru DP, Firake DM, Behere GT. 2016. Assessing risks of pesticides targeting lepidopteran pests in cruciferous ecosystems to eggs parasitoid, Trichogramma brassicae (Bezdenko). Saudi J Biol Sci. DOI: http:// dx.doi.org/10.1016/j.sjbs.2016.04.007

Verma JS, Sharma KC, Sood A, Sood M. 2005. Biology and predatory potential of syrphid predators on Aphis fabae infesting Solanum nigrum L. J Ent Res. 29(1): $39-41$.

Xu HX. 1985. Vertical distribution of Coccinella septempunctata L. and its utilization for control of aphids. Nat Ent Insects 7(4): 204-207. 